\title{
Biodiesel Generation from Palm Kernel Biomass via an In-situ Transesterification Approach
}

\author{
Chikaodili D. Ikechukwu', Ikhazuagbe H. Ifijen ${ }^{2}$, Nyaknno U. Udokpoh ${ }^{2}$ and Esther U. \\ Ikhuoria $^{1}$ \\ ${ }^{1}$ Department of Chemistry, University of Benin, Benin City, Edo State, Nigeria. \\ ${ }^{2}$ Research Operations Department, Rubber Research Institute of Nigeria. \\ *Corresponding author, E-mail: chikadoris2015@gmail.com
}

Received 13 Sep 2021, Revised 22 Dec 2021, Accepted 23 Dec 2021, Published Dec 2021

DOI: https://dx.doi.org/10.4314/tjs.v47i5.29

\begin{abstract}
This study investigated an in-situ transesterification of palm kernel biomass at variable reaction times ( $4 \mathrm{~h}, 5 \mathrm{~h}$ and $6 \mathrm{~h}$ ) and catalyst loading ( $2 \mathrm{wt} \%, 3 \mathrm{wt} . \%$ and $5 \mathrm{wt} . \%)$. The biodiesel yields were observed to vary with these parameters. GC-MS analysis showed high fatty acid methyl esters (FAMEs) contents for all the prepared biodiesel samples (C-18:1, C-14:0, C-16:0, and C18:0). 2 wt.\% catalyst loading and $4 \mathrm{~h}$ reaction time were observed to be the best reaction conditions from the experimented parameters that gave the best biodiesel yield at $300 \mathrm{rpm}$ mixing intensity. The in-situ method recorded a higher degree of oil extraction and efficient conversion of oil to biodiesel (93.93\%) compared to the conventional transesterification method which gave $89.45 \%$. The kinematic viscosity, acid value and iodine value of $3.96 \mathrm{~mm}^{2} / \mathrm{s}, 0.56$

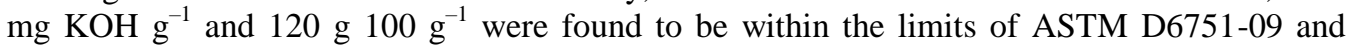
EN14214 standards. These results confirm that efficient production of biodiesel from palm kernel biomass could be possible through an in-situ acidic transesterification process.
\end{abstract}

Keywords: Biodiesel, fatty acid methyl ester, palm kernel biomass, transesterification.

\section{Introduction}

The immense demands for energy consumption in the industrialized world and human existence have increased due to the increase in population (Onaifo et al. 2016, Olugbemide et al. 2020). At the moment, there is depletion in the major sources of nonrenewable energy causing depletion in the ozone layer and climate change (Atadashi et al. 2011). This has resulted in the development of renewable energy sources with little or no environmental pollution when compared to conventional sources. Examples of renewable energies that have been used include geothermal energy, biofuels, solar energy, wind energy, hydrothermal energy, biomass, biofuels and others (Marchetti et al. 2007). Nevertheless, biofuels such as biodiesel are the most widely used fuels in diesel engines for replacing the dwindling conventional petroleum diesel because they have similar properties (Simasatitkul et al. 2011, Giwa et al. 2014, Giwa et al. 2015). The high flash point of biodiesel $\left(150{ }^{\circ} \mathrm{C}\right)$ makes it less volatile and safer to transport and handle (Hoekman et al. 2012).

Biodiesel is a viable alternative transportation fuel that constitutes mono-alkyl esters of long-chain fatty acids from vegetable oils or animal fats (Kukana and Jakhar 2021). It is also known as a carbon-neutral fuel and a national product that reduces the dependency on foreign energy resources and creates jobs for the economy (Fukuda et al. 2001). It enjoys a positive social impact, by promoting rural revitalization (Kiss et al. 2006) and converting waste materials of no economic value to products with a more improved worth. Biodiesel is composed of long-chain hydrocarbon groups with essentially no 
branching or aromatic structures. The presence of a significant amount of oxygen $(9 \%)$ in its structure makes its combustion efficiency higher than that of petroleum diesel (Hoekman et al. 2012). Previous studies have produced biodiesel from high-oil content agricultural products such as coconut, palm oil, soybean oil, Jojoba oil, rice bran, sunflower, canola, rapeseed, soybean, sunflower oil, neem oil, peanut oil and cottonseed oil via the transesterification process (Hailegiorgis et al. 2011, Sinha et al. 2008, Issariyakul and Dalai 2010, Maliki and Ifijen 2020, Ifijen and Nkwor 2020, Maliki et al. 2020). This process involves the reaction of an alkyl-alcohol with a long chain ester linkage to yield mono-alkyl esters (biodiesel) and glycerol in the presence or absence of a catalyst to chemically break the molecule of triglyceride (Ifijen et al. 2018, Kafuku et al. 2010).

Several alternative fuels such as biogas, producer gas, ethanol, methanol and vegetable oils have been utilized. However, biodiesel offers an advantage because of its comparable fuel properties with that of petroleum diesel and its renewable and environmentally friendly nature (Zaher and Gad 2016). Biodiesel releases less particulate emissions, soot and carbon monoxide than petroleum-based fuels (Aalam and Saravanan 2015, Selvakumar et al. 2015, Ahmed et al. 2016). This eco-friendly property has led to its use in many countries, especially in environmentally sensitive areas like Malaysia, Thailand, South Korea, USA, Philippines, Indonesia, China, Australia, Argentina, Malaysia, Brazil, Czech Republic, Germany, France, Italy, Slovakia, Spain, etc. A major challenge to biodiesel commercialization as an alternate fuel to petroleum diesel is the cost of production. However, the cost can be reduced by the increase in feedstock supply through the expansion of current agricultural lands or the development of new sources of vegetable oils (Demirbas 2008). Several kinds of bio-based fuels such as vegetable oils (raw, refined, or used), oil methyl esters, and liquid biomass fuels as options to fossil fuels have been studied (Karabas et al. 2014). To be as efficient substitutes for petroleum diesel, vegetable oils have to be modified. The four primary techniques that can be used in the modification are micro-emulsion, dilution, transesterification and pyrolysis (thermal cracking) (Kumar and Sharma 2011). The leading technique for the advancement of an eco-friendly sustainable and reliable fuel from raw vegetable oils is transesterification (Aalam and Saravanan 2015). The transesterification process has been proposed by several studies as one of the encouraging techniques for converting vegetable oils to fatty acid alkyl esters that can be utilized in diesel fuel-based engines. The factors that affect transesterification are catalytic concentration, methanol-to-oil molar ratio, reaction temperature, reaction time and free fatty acid content (Thoai et al. 2019). Biodiesel is a fuel that is sustainable, biodegradable, environmentally safe, and nontoxic and can be applied without any engine remodeling in conventional diesel engines with consistent performance. This study made use of an in-situ transesterification process to increase the conversion of biodiesel. In-situ transesterification, therefore, facilitates the conversion of the biomass oil to biodiesel directly from the oil-bearing biomass through the simultaneous extraction and transesterification process of the biomass oil (Ehimen et al. 2010). The major advantage of this process is the capability of generating biodiesel from oilseeds without first carrying out oil extraction and the low amount of solvent/catalyst required during the extraction/synthetic steps. This helps to overcome the challenges of the large amounts of hazardous solvent wastes produced from the oil extraction/transesterification processes (Li et al. 2011). As a consequence, this method has proven to be an efficient and economical method to produce biodiesel compared to the conventional route (Johnson and Wen 2009).

This study generated biodiesel from palm kernel biomass via an in-situ transesterification process and investigated the certain reaction conditions such as the effects of catalyst loading and reaction time on the biodiesel yields. 


\section{Materials and Methods: Experimental Chemicals}

Methanol, hexane, tetraoxosulphate(VI) acid, calcium chloride, sodium thiosulphate, potassium iodide, potassium hydroxide, calcium oxide, phenolphthalein solution, starch solution, Wijis solution and distilled water were used. All reagents were of analytical grade.

\section{Biomass and sample preparation}

The palm kernel seed samples used in this work were obtained from Oluku in Benin City, Edo State, Nigeria. The obtained seeds were screened to remove the defected seeds, sundried and cracked to obtain the kernel seeds. Thereafter, they were washed, sundried and ground into powder form. The seeds samples were repeatedly weighed and dried in the oven at $105{ }^{\circ} \mathrm{C}$ until a constant weight was achieved.

In-situ transesterification palm kernel biomass
To reduce moisture content, pre-treatments of the milled palm kernel were carried out using methanol as described by Qian et al. (2013). The in-situ transesterification process was carried out as described by Johnson and Wen (2009). In a typical experiment, $120 \mathrm{~g}$ of milled palm kernel biomass was placed in a 1 L three-neck round bottom flask with a reflux condenser and mixed with methanolic solution containing sulfuric acid, which was freshly prepared to maintain its catalytic activity. n-Hexane (95\% purity) and a calcium oxide catalyst concentration of 2 wt.\% were then added to the mixture of methanol and sulfuric acid. The reaction temperature was maintained at $50{ }^{\circ} \mathrm{C}$ for $4 \mathrm{~h}$. The reaction mixture was filtered, centrifuged and separated to obtain the biodiesel (fatty acid methyl esters (FAMEs)) which was washed with warm distilled water and also dried with calcium chloride. Other biodiesel samples were similarly prepared by varying the reaction parameters at a constant stirring speed of $300 \mathrm{rpm}$. The chemistry of the biodiesel synthesis is depicted in Scheme 1.

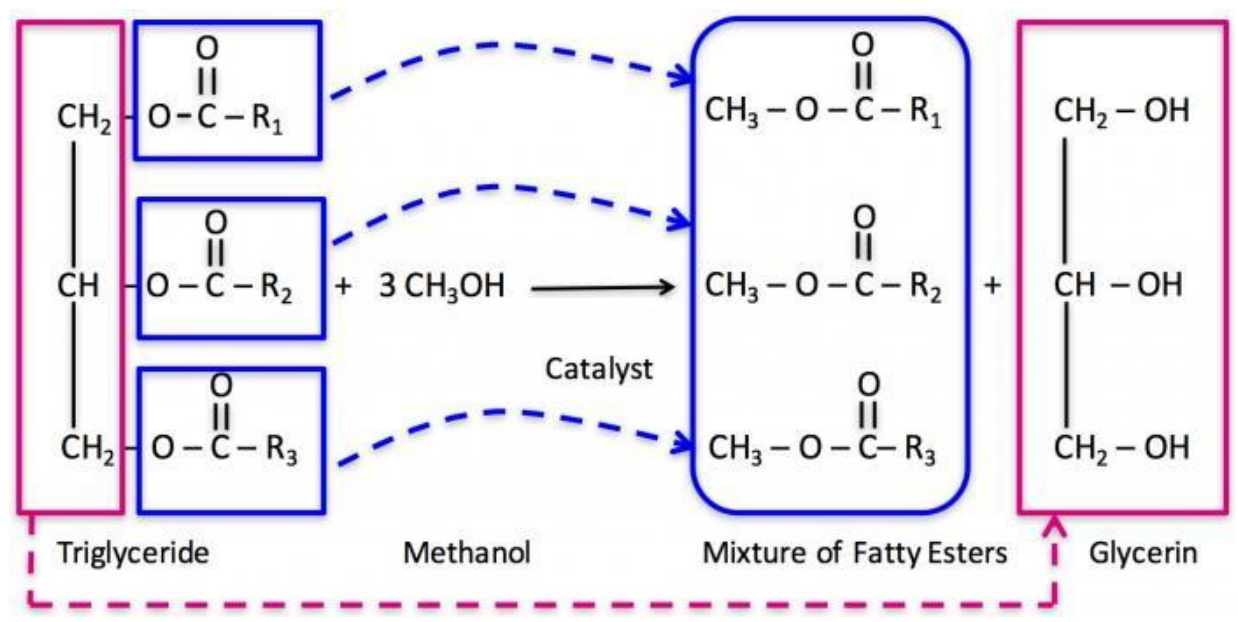

Scheme 1: Chemistry of biodiesel production.

\section{Characterization technique}

The fatty acid methyl esters (FAMEs) present in the generated biodiesel were characterized using GC-MS with a variable split-flow injector (Agilent 7890, Agilent Technologies) coupled with a mass selective detector (mass spectrometer) of 5975 Agilent technologies equipped with a HP5MS Agilent technologies capillary GC column (length of $30 \mathrm{~m}$, internal diameter of $0.320 \mathrm{~mm}, 0.25$ $\mathrm{mm}$ Agilent HP-5MS column (film thickness of $0.25 \mu \mathrm{m})$. The injector and detector temperatures are $250{ }^{\circ} \mathrm{C}$ and $280{ }^{\circ} \mathrm{C}$, respectively. Helium was used as the carrier gas. 


\section{Results and Discussion}

Table 1 reveals the fuel features of biodiesel synthesized via an in-situ transesterification process. The results revealed that the acid values of the developed biodiesel samples were within the detailed limits of ASTM (0.8 $\max \mathrm{mg} \mathrm{KOH} \mathrm{g}^{-1}$ ) standards, confirming that the free fatty acids have been totally transformed to biodiesel (Kiss et al. 2006). The determination of a fluid's internal resistance to the flow of biodiesel under gravitational forces is known as kinematic viscosity. It is an indicator of fuel atomization and complete combustion in the diesel engine. The generated biodiesel samples were within the range of kinematic viscosity specifications (determinations at $40{ }^{\circ} \mathrm{C}$ ) of $1.9-6.0 \mathrm{~mm}^{2} / \mathrm{s}$ and $3.5-5.0 \mathrm{~mm}^{2} / \mathrm{s}$ specified by the American standard ASTM D6751 and European standard EN 14214, respectively (Knothe and Steidley 2005). The observed kinematic viscosity suggests that the prepared biodiesel will provide sufficient lubrication for fuel injection pumps, resulting in decreased wear (Noureddini et al. 1992). Iodine value is an essential quality parameter for estimating biodiesel oxidative stability. It can be used to determine the degree of unsaturation of the biodiesel (Knothe 2002). The observed iodine values were within the ASTM standards (ASTM 1998). Notwithstanding, some of the iodine values of the generated biodiesel samples were slightly higher than the ASTM standard.

Table 1: Effects of the reaction process variables on the physiochemical properties of biodiesel produced

\begin{tabular}{|c|c|c|c|c|c|c|}
\hline & \multicolumn{3}{|c|}{ Catalyst loading (\%) } & \multicolumn{3}{|c|}{ Reaction time (h) } \\
\hline $\begin{array}{l}\text { Biodiesel } \\
\text { characteristics }\end{array}$ & 2 & 3 & 5 & 4 & 5 & 6 \\
\hline Appearance & Light yellow & $\begin{array}{l}\text { Light } \\
\text { yellow }\end{array}$ & $\begin{array}{l}\text { Light } \\
\text { yellow }\end{array}$ & $\begin{array}{l}\text { Light } \\
\text { yellow }\end{array}$ & $\begin{array}{l}\text { Light } \\
\text { yellow }\end{array}$ & $\begin{array}{l}\text { Light } \\
\text { yellow }\end{array}$ \\
\hline $\begin{array}{l}\text { Acid value mg KOH } \\
\mathrm{g}^{-1}\end{array}$ & 0.56 & 0.56 & 0.51 & 0.56 & 0.59 & 0.73 \\
\hline Iodine value $\mathrm{g} 100 \mathrm{~g}^{-1}$ & 120 & 119 & 116 & 120 & 122 & 120 \\
\hline $\begin{array}{l}\text { Kinematic viscosity } \\
\text { (at } 26^{\circ} \mathrm{C} \text { ) } \mathrm{mm}^{2} / \mathrm{s}\end{array}$ & 3.96 & 3.51 & 2.80 & 3.96 & 2.48 & 2.42 \\
\hline
\end{tabular}

\section{Effects of variable weight of catalyst loading}

The extraction rate of $9.44 \%$ makes methanol a poor solvent whenever it is used in lipid extraction (Qian et al. 2008). Hence, catalysts will assist in breaking the cell walls of the oilseed to enable the methanol to react with the oil. The consequence of the weight of catalyst loading on the in-situ transesterification reaction was investigated by adopting three different weights of catalyst loading, 2 wt. $\%, 3$ wt. $\%$ and 5 wt. $\%$ of $\mathrm{CaO}$ that have been activated with methanol at room temperature. Figures 1-3 and Tables 24 revealed the detected fatty acid methyl esters (FAMEs) of the biodiesel samples at variable catalysts loading obtained from the GC-MS analysis. The generated yields of fatty acid methyl esters from the catalytic performance of hydrogen tetraoxosulphate (vi) acid $\left(\mathrm{H}_{2} \mathrm{SO}_{4}\right)$ at varying catalytic loading of 2 wt. $\%, 3$ wt. $\%$ and 5 wt. $\%$ were very good. An increase in the catalytic loading led to a remarkable improvement in the FAMEs yields from 96.24 to $97.87 \%$ and then to $99.99 \%$. This may be ascribed to the unusual surface area of the catalyst and its comparatively simple diffusion rate in the mesopores. The impact of the catalyst on the FAME yields was relatively predominant and the utilized acid catalyst $\left(\mathrm{H}_{2} \mathrm{SO}_{4}\right)$ also exhibited tremendous potential as a catalyst for biodiesel generation. Consequently, this proves that tremendous FAMEs can be accomplished by employing the acidcatalyzed in-situ transesterification technique. Furthermore, high content of methyl tetradecanoate (C14:0), octadecenoic acid 
methyl ester (C18:1), methyl stearate (C18:0) and hexadecanoic acid methyl ester (C16:0) at multiple catalyst loading were obtained by the biodiesel fatty acid profiling. Octadecanoic acid methyl ester had the highest amount of fatty acid methyl ester content (37-40\%), while methyl stearate $(6-8 \%)$ showed the lowest fatty acid methyl ester content. The amounts of octadecenoic acid methyl ester (C-18:1) and methyl stearate (C-18:0) were seen to be the highest at 5 wt.\% and lowest at 2 wt.\% apiece. Notwithstanding, greater amounts of hexadecanoic acid methyl ester
(C-16:0) and methyl tetradecanoate (C-14:0) were recorded by $2 \mathrm{wt}$. \% catalyst loading, whereas the lowest amounts of C-14:0 and C16:0 were observed at 3 wt. $\%$ and 5 wt. $\%$ catalyst loading, respectively. Total saturated fatty acid methyl esters (SAFA) of $59.09 \%$, $57.34 \%$ and $55.97 \%$ were demonstrated at catalytic loading of 2 wt. $\%, 3$ wt.\%, and 5 wt.\%, respectively. Also, total monounsaturated fatty acid contents (MUFA) of $37.15 \%, 39.53 \%$ and $40.03 \%$ were revealed at the aforementioned catalyst loading.

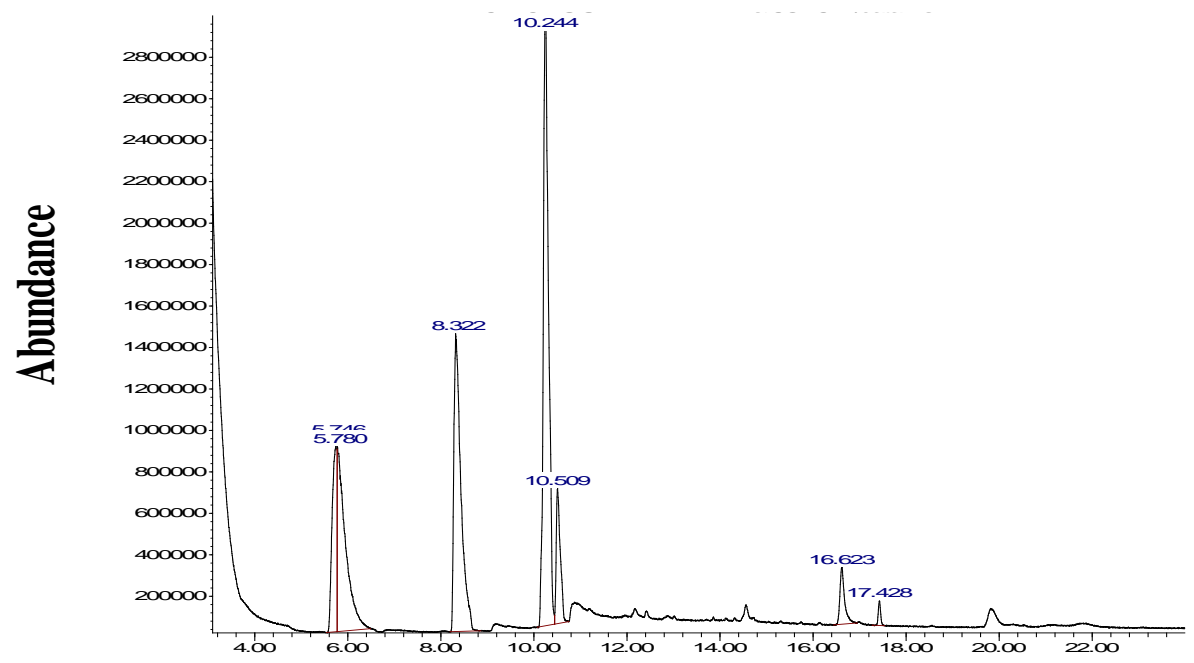

Time

Figure 1: Chromatogram of the observed fatty acid methyl esters at 2wt. \% catalyst loading.

Table 2: Fatty acid methyl esters detected at 2 wt. $\%$ catalyst loading

\begin{tabular}{lllll}
\hline $\begin{array}{l}\text { Names of fatty acid methyl esters } \\
\text { (FAMEs) }\end{array}$ & $\begin{array}{l}\text { Retention } \\
\text { time } \\
\text { (mins) }\end{array}$ & $\begin{array}{l}\text { FAMEs } \\
\text { yield (\%) }\end{array}$ & $\begin{array}{l}\text { Molecular } \\
\text { formula }\end{array}$ & $\begin{array}{l}\text { Molecular } \\
\text { weight }\end{array}$ \\
\hline $\begin{array}{l}\text { Methyl tetradecanoate } \\
\text { Hexadecanoic acid, methyl ester }\end{array}$ & $\begin{array}{l}8.763 \\
8.322\end{array}$ & 28.086 & $\mathrm{C}_{15} \mathrm{H}_{30} \mathrm{O}_{2}$ & 24.534 \\
$\begin{array}{l}\mathrm{C}_{17} \mathrm{H}_{34} \mathrm{O}_{2} \\
\text { 9-Octadecenoic acid, methyl ester }\end{array}$ & 10.244 & 37.152 & $\mathrm{C}_{19} \mathrm{H}_{36} \mathrm{O}_{2}$ & 296 \\
$\begin{array}{l}\text { (E)-11-Octadecenoic acid, methyl } \\
\text { ester }\end{array}$ & & & & \\
$\begin{array}{l}\text { Cis-13-Octadecenoic acid, methyl } \\
\text { ester }\end{array}$ & & & & \\
$\begin{array}{l}\text { Methyl stearate } \\
\text { \% Total }\end{array}$ & 10.509 & 6.472 & $\mathrm{C}_{19} \mathrm{H}_{38} \mathrm{O}_{2}$ & 298 \\
\hline
\end{tabular}




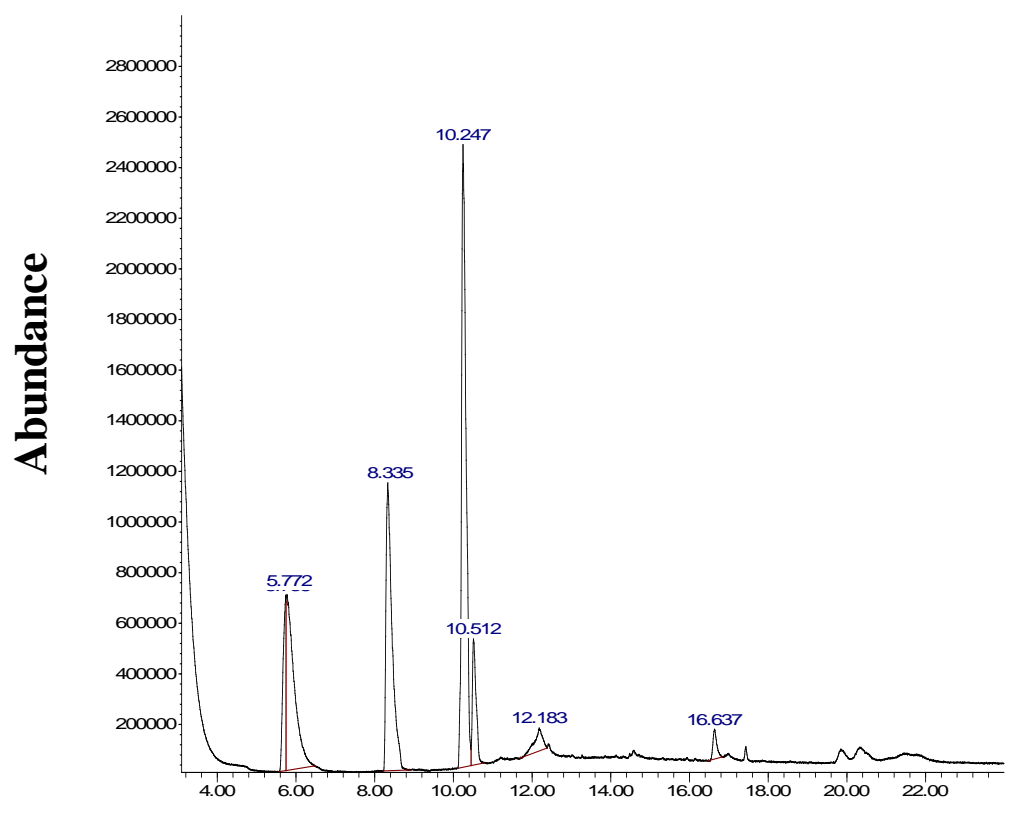

\section{Time}

Figure 2: Chromatogram of the observed fatty acid methyl esters at $3 \mathrm{wt}$. \% catalyst loading.

Table 3: Detected fatty acid methyl esters at 3 wt.\% catalyst loading

\begin{tabular}{lllll}
\hline $\begin{array}{l}\text { Names of fatty acid methyl esters } \\
\text { (FAMEs) }\end{array}$ & $\begin{array}{l}\text { Retention } \\
\text { time } \\
\text { (mins) }\end{array}$ & $\begin{array}{l}\text { FAMEs } \\
\text { yield (\%) }\end{array}$ & $\begin{array}{l}\text { Molecular } \\
\text { mass }\end{array}$ & $\begin{array}{l}\text { Molecular } \\
\text { formula }\end{array}$ \\
\hline $\begin{array}{l}\text { Methyl tetradecanoate } \\
\text { Hexadecanoic acid, methyl ester }\end{array}$ & 5.738 & 26.386 & 242 & $\mathrm{C}_{15} \mathrm{H}_{30} \mathrm{O}_{2}$ \\
$\begin{array}{l}\text { 9-Octadecenoic acid, methyl ester } \\
\text { (E)-11-Octadecenoic acid, methyl ester }\end{array}$ & 10.335 & 24.360 & 270 & $\mathrm{C}_{17} \mathrm{H}_{34} \mathrm{O}_{2}$ \\
$\begin{array}{l}\text { Cis-13-Octadecenoic acid, methyl ester } \\
\text { Methyl stearate }\end{array}$ & 10.512 & 39.530 & 296 & $\mathrm{C}_{19} \mathrm{H}_{36} \mathrm{O}_{2}$ \\
\% Total & & 6.596 & 298 & \\
\hline
\end{tabular}




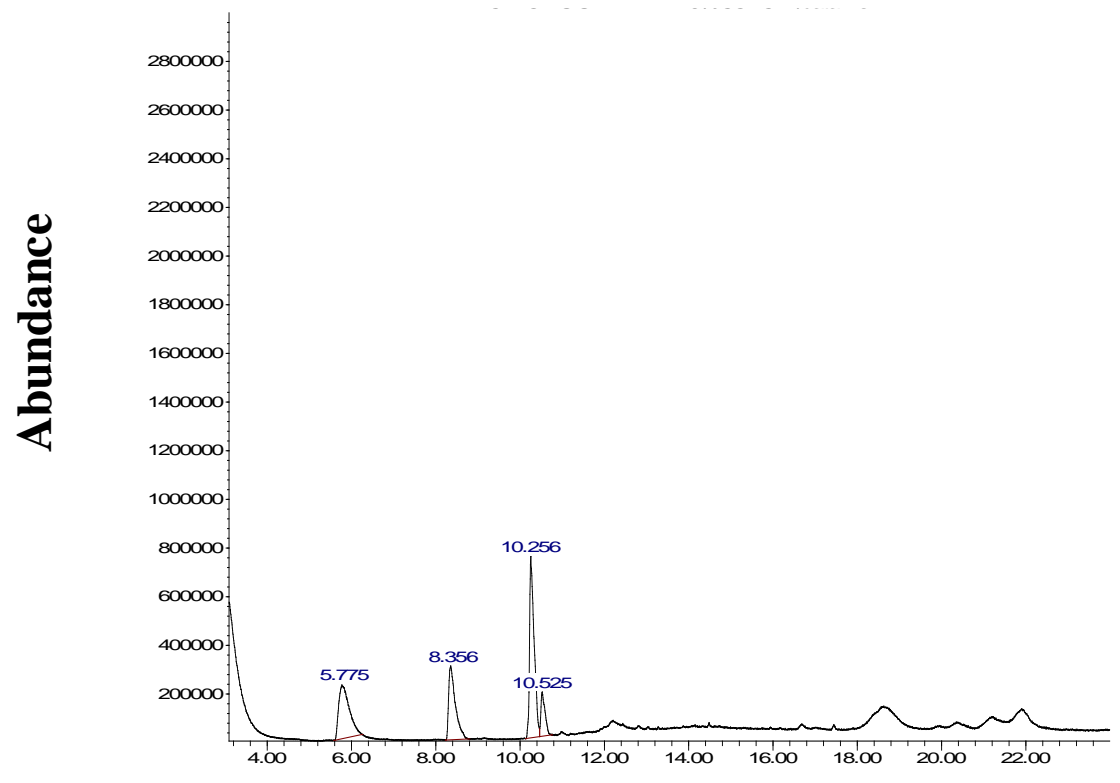

Time

Figure 3: Fatty acid methyl esters revealed at $5 \mathrm{wt} . \%$ catalyst loading.

Table 4: Detected fatty acid methyl esters at 5 wt. $\%$ catalyst loading

\begin{tabular}{|c|c|c|c|c|}
\hline $\begin{array}{l}\text { Names of fatty acid methyl } \\
\text { esters (FAMEs) }\end{array}$ & $\begin{array}{l}\text { Retention } \\
\text { time (mins) }\end{array}$ & $\begin{array}{l}\text { FAMEs } \\
\text { yield }(\%)\end{array}$ & $\begin{array}{l}\text { Molecular } \\
\text { weight }\end{array}$ & $\begin{array}{l}\text { Molecular } \\
\text { formula }\end{array}$ \\
\hline Methyl tetradecanoate & 5.775 & 27.368 & 242 & $\mathrm{C}_{15} \mathrm{H}_{30} \mathrm{O}_{2}$ \\
\hline $\begin{array}{l}\text { Hexadecanoic acid, methyl } \\
\text { ester }\end{array}$ & 8.356 & 23.786 & 270 & $\mathrm{C}_{17} \mathrm{H}_{34} \mathrm{O}_{2}$ \\
\hline \multicolumn{5}{|l|}{$\begin{array}{l}\text { Pentadecanoic acid, 14-methyl } \\
\text { ester }\end{array}$} \\
\hline $\begin{array}{l}\text { (Z)-9-Octadecenoic } \\
\text { methyl ester }\end{array}$ & 10.256 & 40.034 & 296 & $\begin{array}{l}\mathrm{C}_{19} \mathrm{H}_{36} \mathrm{O}_{2} \\
\mathrm{C}_{19} \mathrm{H}_{36} \mathrm{O}_{2}\end{array}$ \\
\hline $\begin{array}{l}\text { 8-Octadecenoic acid, methyl } \\
\text { ester }\end{array}$ & & & & $\mathrm{C}_{19} \mathrm{H}_{36} \mathrm{O}_{2}$ \\
\hline $\begin{array}{l}\text { (Z)-6-Octadecenoic } \\
\text { methyl ester }\end{array}$ & & & & \\
\hline Methyl stearate & 10.525 & 8.811 & 298 & $\mathrm{C}_{19} \mathrm{H}_{38} \mathrm{O}_{2}$ \\
\hline \% Total & & 99.999 & & \\
\hline
\end{tabular}

\section{Effects of variation in reaction time}

The most significant factor which influences in-situ transesterification is the reaction time (Qian et al. 2013). The effectiveness of biodiesel production and the characteristic of biodiesel outcomes can be influenced by reaction time. The reaction time was varied from $4 \mathrm{~h}$ to $6 \mathrm{~h}$ to study its effects in the in-situ transesterification of palm kernel using
$\mathrm{CaO}$ catalyst. Figures 4-6 and Tables 5-7 depict the detected fatty acid methyl esters (FAMEs) of the biodiesel samples obtained from the GC-MS analysis at variable reaction times of $4 \mathrm{~h}, 5 \mathrm{~h}$, and $6 \mathrm{~h}$. There was an increase in the yields of the FAMEs from $96.88 \%$ to $97.85 \%$ and finally to $99.94 \%$ as the reaction period was extended. This suggests that the FAME yield improves as the reaction period is 
prolonged. The highest yields of FAMEs obtained at the variable times of $4 \mathrm{~h}, 5 \mathrm{~h}$, and $6 \mathrm{~h}$ were observed to be $37.792 \%$, $34.406 \%$ and $37.870 \%$ for 9 -octadecenoic acid methyl ester, $(E)$-9-octadecenoic acid methyl ester and 11-octadecenoic acid methyl ester, respectively. The lowest contents were seen at $6.472 \%, 0.310 \%$ and $7.797 \%$ for methyl stearate, 9,12octadecadienoic acid $(Z, Z)$-methyl ester, and methyl stearate, respectively. The total saturated fatty acid methyl ester contents (SAFA) at various reaction times of $4 \mathrm{~h}, 5$ $\mathrm{h}$ and $6 \mathrm{~h}$ were observed to be $59.09 \%$, $62.27 \%$, and $62.13 \%$, and the total monounsaturated fatty acid contents (MUFA) were found to be $37.79 \%, 34.41 \%$ and $37.87 \%$, respectively. However, polyunsaturated fatty acid methyl acid (PUFA) content was only observed in the sample fabricated adopting the $5 \mathrm{~h}$ reaction time to be $1.17 \%$.

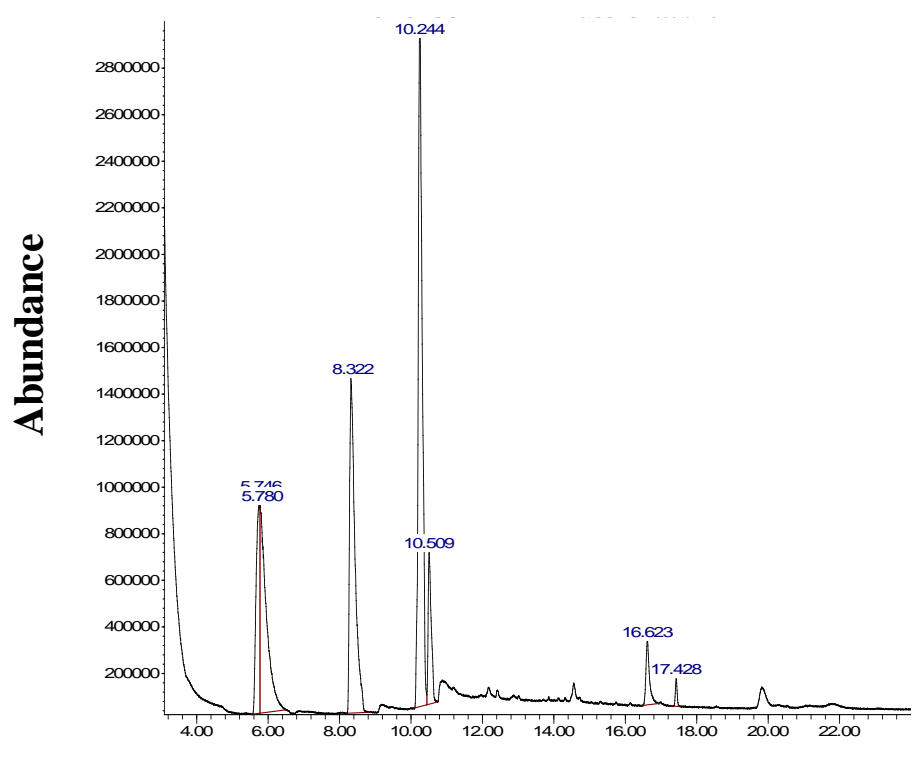

Time

Figure 4: Chromatogram of the observed fatty acid methyl esters at $4 \mathrm{~h}$ reaction time.

Table 5: Detected fatty acid methyl esters at $4 \mathrm{~h}$ reaction time

\begin{tabular}{|c|c|c|c|c|}
\hline $\begin{array}{l}\text { Names of fatty acid methyl esters } \\
\text { (FAMEs) }\end{array}$ & $\begin{array}{l}\text { Retention } \\
\text { time (mins) }\end{array}$ & $\begin{array}{l}\text { FAMEs } \\
\text { yield }(\%)\end{array}$ & $\begin{array}{l}\text { Molecular } \\
\text { weight }\end{array}$ & $\begin{array}{l}\text { Molecular } \\
\text { formula }\end{array}$ \\
\hline Methyl tetradecanoate & 5.746 & 10.214 & 242 & $\mathrm{C}_{15} \mathrm{H}_{30} \mathrm{O}_{2}$ \\
\hline Methyl tetradecanoate & 5.780 & 17.872 & 242 & $\mathrm{C}_{15} \mathrm{H}_{30} \mathrm{O}_{2}$ \\
\hline Hexadecanoic acid, methyl ester & 8.322 & 24.534 & 270 & $\mathrm{C}_{17} \mathrm{H}_{34} \mathrm{O}_{2}$ \\
\hline $\begin{array}{l}\text { 9-Octadecenoic acid, methyl } \\
\text { ester }\end{array}$ & 10.244 & 37.792 & 296 & $\mathrm{C}_{19} \mathrm{H}_{36} \mathrm{O}_{2}$ \\
\hline $\begin{array}{l}(E) \text {-11-Octadecenoic acid, } \\
\text { methyl ester }\end{array}$ & & & & \\
\hline $\begin{array}{l}\text { Cis-13-Octadecenoic } \\
\text { methyl ester }\end{array}$ & & & & \\
\hline $\begin{array}{l}\text { Methyl stearate } \\
\% \text { Total }\end{array}$ & 10.509 & $\begin{array}{l}6.472 \\
96.884\end{array}$ & 298 & $\mathrm{C}_{19} \mathrm{H}_{38} \mathrm{O}_{2}$ \\
\hline
\end{tabular}




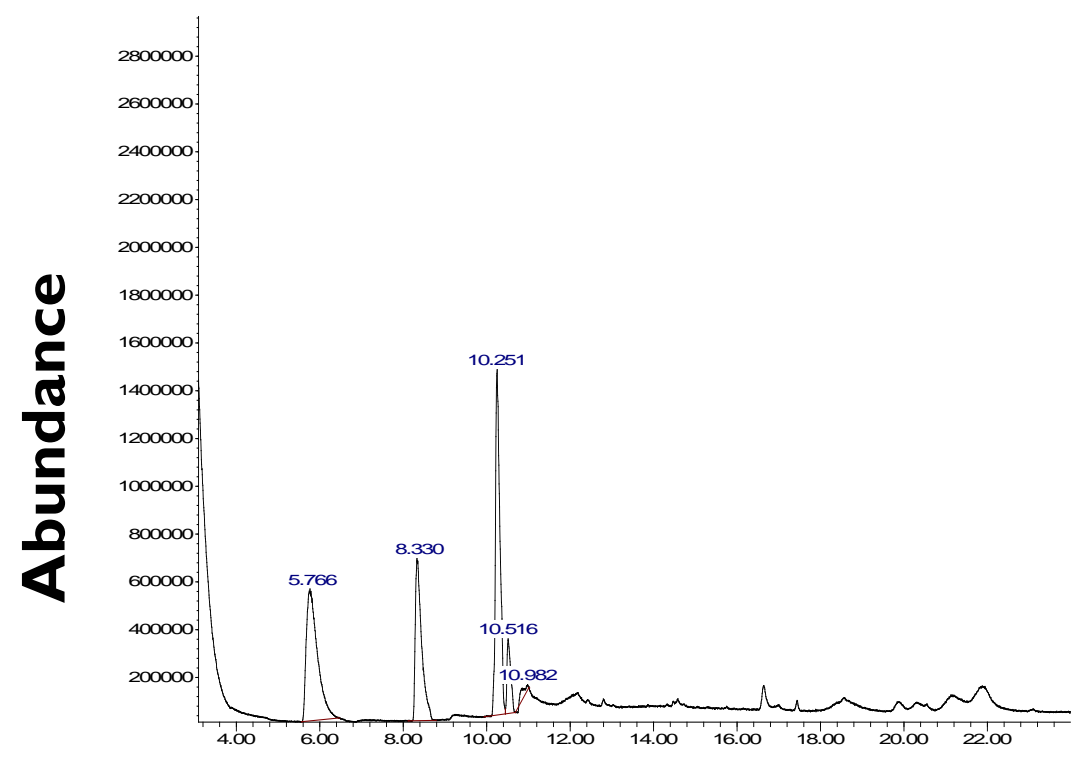

\section{Time}

Figure 5: Chromatogram of the observed fatty acid methyl esters at $5 \mathrm{~h}$ reaction time.

Table 6: Detected fatty acid methyl esters at $5 \mathrm{~h}$ reaction time

\begin{tabular}{|c|c|c|c|c|c|}
\hline $\begin{array}{l}\text { Names of fatty acid } \\
\text { esters (FAMEs) }\end{array}$ & methyl & $\begin{array}{l}\text { Retention } \\
\text { time } \\
\text { (mins) }\end{array}$ & $\begin{array}{l}\text { FAMEs } \\
\text { yield }(\%)\end{array}$ & $\begin{array}{l}\text { Molecular } \\
\text { Weight }\end{array}$ & $\begin{array}{l}\text { Molecular } \\
\text { formula }\end{array}$ \\
\hline Methyl tetradecanoate & & 5.766 & 33.012 & 242 & $\mathrm{C}_{15} \mathrm{H}_{30} \mathrm{O}_{2}$ \\
\hline $\begin{array}{l}\text { Hexadecanoic acid, } \\
\text { ester }\end{array}$ & methyl & 8.330 & 22.999 & 270 & $\mathrm{C}_{17} \mathrm{H}_{34} \mathrm{O}_{2}$ \\
\hline $\begin{array}{l}(E) \text {-9-Octadecenoic } \\
\text { methyl ester }\end{array}$ & acid, & 10.251 & 34.406 & 296 & $\mathrm{C}_{19} \mathrm{H}_{36} \mathrm{O}_{2}$ \\
\hline $\begin{array}{l}\text { Cis-13-Octadecenoic } \\
\text { methyl ester }\end{array}$ & acid, & & & & \\
\hline $\begin{array}{l}\text { 11-Octadecenoic acid, } \\
\text { ester }\end{array}$ & methyl & & & & \\
\hline Methyl stearate & & 10.516 & 6.262 & 298 & $\mathrm{C}_{19} \mathrm{H}_{38} \mathrm{O}_{2}$ \\
\hline Linoelaidic acid methyl & ester & 10.562 & 0.864 & 294 & $\mathrm{C}_{19} \mathrm{H}_{34} \mathrm{O}_{2}$ \\
\hline $\begin{array}{l}\text { 9,12-Octadecadienoic } \\
\text { (Z,Z)- methyl ester }\end{array}$ & acid & & & & \\
\hline $\begin{array}{l}\text { 9,12-Octadecadienoic } \\
\text { (Z,Z)- methyl ester }\end{array}$ & acid & 10.982 & 0.310 & 294 & $\mathrm{C}_{19} \mathrm{H}_{34} \mathrm{O}_{2}$ \\
\hline$\%$ Total & & & 97.853 & & \\
\hline
\end{tabular}




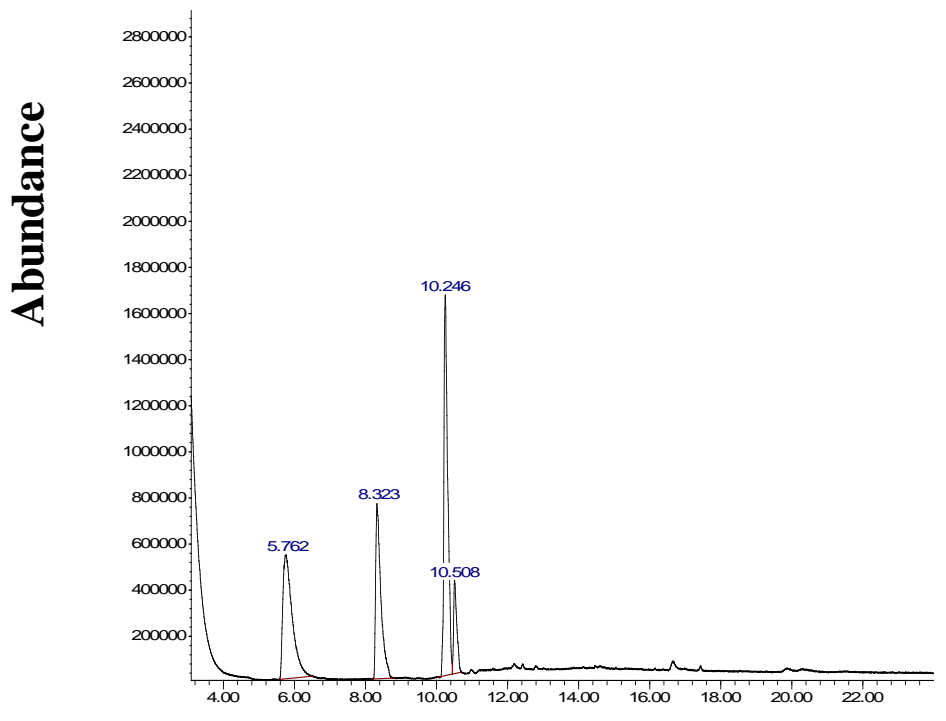

Time

Figure 6: Chromatogram of the observed fatty acid methyl esters at $6 \mathrm{~h}$ reaction time.

Table 7: Detected fatty acid methyl esters at $6 \mathrm{~h}$ reaction time

\begin{tabular}{lllll}
\hline $\begin{array}{l}\text { Names of fatty acid of methyl } \\
\text { esters (FAMEs) }\end{array}$ & $\begin{array}{l}\text { Retention } \\
\text { time (min) }\end{array}$ & $\begin{array}{l}\text { FAMEs } \\
\text { yield }\end{array}(\%)$ & $\begin{array}{l}\text { Molecular } \\
\text { weight }\end{array}$ & $\begin{array}{l}\text { Molecular } \\
\text { formula }\end{array}$ \\
\hline $\begin{array}{l}\text { Methyl tetradecanoate } \\
\text { Hexadecanoic acid, methyl ester }\end{array}$ & $\begin{array}{l}5.762 \\
8.323\end{array}$ & 30.526 & 242 & $\mathrm{C}_{15} \mathrm{H}_{30} \mathrm{O}_{2}$ \\
$\begin{array}{l}\text { 11-Octadecenoic acid, methyl } \\
\text { ester }\end{array}$ & 10.246 & 37.8708 & 270 & $\mathrm{C}_{17} \mathrm{H}_{34} \mathrm{O}_{2}$ \\
$\begin{array}{l}\text { (E)-9-Octadecenoic acid, methyl } \\
\text { ester }\end{array}$ & & 296 & $\mathrm{C}_{19} \mathrm{H}_{36} \mathrm{O}_{2}$ \\
$\begin{array}{l}\text { Cis-13-Octadecenoic acid, methyl } \\
\text { ester }\end{array}$ & & & \\
$\begin{array}{l}\text { Methyl stearate } \\
\% \text { Total }\end{array}$ & 10.508 & 7.797 & 298 & \\
\hline
\end{tabular}

\section{Conclusions}

An in-situ transesterification process can be successfully used to generate biodiesel from palm kernel biomass with fuel properties that are within ASTM standards. The yield of biodiesel from palm kernel seed was observed to be significantly influenced by catalyst loading, reaction time and reaction temperature. Optimal conditions for biodiesel yields in this investigation were about $2 \mathrm{wt} \%$ catalyst loading and $4 \mathrm{~h}$ reaction time.

\section{References}

Ahmed F, Giwa SO, Ibrahim M and Giwa A 2016 Production of biodiesel from
Jatrophacurcas seed oil using base catalyzed transesterification. Int. J. ChemTech Res. 9(6): 322-332.

American Society for Testing and Materials (ASTM) 1998 Standard Specification for Biodiesel Fuel (B100) Blend Stock for Distillate Fuels. Designation ASTM D 6751, ASTM International, West Conshohocken, PA.

Aalam CS and Saravanan CG 2015 Biodiesel production from Mahua Oil via catalytic transesterification method. Int. J. Chem. Technlo. Res. 8(4): 1706-1709. 
Atadashi IM, Aroua MK and Aziz AA 2011 Biodiesel separation and purification: a review. Renew. Energy 36: 437-443.

Demirbas A 2008 Biofuels sources, biofuel policy, biofuel economy and global biofuel projections. Energy Convers. Manag. 49(8): 2106-2116.

Ehimen EA, Sun ZF, Carrington CG 2010 Variables affecting the in-situ transesterification of microalgae lipids. Fuel 89(3): 677-684.

Fukuda H, Kondo A and Noda H 2001 Biodiesel fuel production by transesterification of oils. J. Biosci. Bioeng. 92: 405-416.

Giwa A, Bello A and Giwa SO 2014 Performance analyses of fatty acids in reactive distillation process for biodiesel production. Int. J. Sci. Eng. Res. 5(12): 529-540.

Giwa A, Bello A and Giwa SO 2015 Artificial neural network modeling of a reactive distillation process for biodiesel production. Int. J. Sci. Eng. Res. 6(1): 1175-1191.

Hailegiorgis SM, Mahadzir S and Subbarao D 2011 Enhanced in-situ ethanolysis of Jatrophacurcas $L$. in the presence of cetyltrimethylammonium bromide as a phase transfer catalyst. Renew. Energy 36(9): 2502-2507.

Hoekman SK, Broch A, Robbins C, Ceniceros E and Natarajan M 2012 Review of biodiesel composition, properties, and specifications. Renew. Sustain. Energy Rev. 16(1): 143-169.

Issariyakul T and Dalai KA 2010 Biodiesel production from greenseed canola oil. Energy Fuels 24: 4652-4658.

Ifijen IH, Ikhuoria EU, Omorogbe SO, Agbonlahor OG 2018 Comparative studies on the use of palm kernel and coconut oil as biodiesel fuel sources. Int. J. Green Chem. 4(1): 19-24.

Ifijen HI and Nkwor AN 2020 selected underexploited plant oils in Nigeria: A correlative study of their physiochemical properties. Tanz. J. Sci. 46(3): 817-827.

Johnson MB and Wen Z 2009 Production of biodiesel fuel from the microalga Schizochytrium limacinum by direct transesterification of algal biomass. Energy Fuels 23(10): 5179-5183.

Kafuku G, Lam MK, Kansedo J, Lee KT and Mbarawa M 2010 Croton megalocarpus oil: a feasible non-edible oil source for biodiesel production. Bioresour. Technol. 101(18): 7000-7004.

Karabas H 2014 Application of the Taguchi method for the optimization of effective parameters on the safflower seed oil methyl ester production. Int. J. Green Energy 11(9): 1002-1012.

Kiss AA, Dimian AC and Rothenberg G 2006 Solid acid catalysts for biodiesel production-towards sustainable energy. Adv. Synth. Catal. 348(1-2): 75-81.

Knothe G and Steidley KR 2005 Kinematic viscosity of biodiesel fuel components and related compounds. Influence of compound structure and comparison to petro-diesel fuel components. Fuel 84: 1059-1065.

Knothe G 2000 Structure indices in FA chemistry. How relevant is the iodine value? J. Am. Oil Chem. Soc. 79: 847-853.

Kumar A and Sharma S 2011 Potential nonedible oil resources as biodiesel feedstock: An Indian perspective. Renew. Sustain. Energy Rev. 15(4): 1791-1800.

Kukana R and Jakhar OP 2021 Synthesis of biodiesel from Prosopis juliflora and using MCDM analytical hierarchy process technique for evaluating with different biodiesel. Cogent Engineering 8(1): 1957291.

Li P, Miao X, Li R and Zhong J 2011 In-situ biodiesel production from fast-growing and high oil content Chlorella pyrenoidosa in rice straw hydrolysate. $J$. Biomed. Biotechnol. 2011: 1-8.

Marchetti JM, Miguel VU and Errazu AF 2007 Possible methods for biodiesel production. Renewable and Sustainable Energy Reviews 11: 1300-1311.

Maliki M, Ikhuoria EU and Ifijen IH 2020 Extraction and physicochemical characterization of oils obtained from selected under-utilized oil bearing seeds in Nigeria. Chem Search J. 11(1): 110-117. 
Maliki M and Ifijen IH 2020 Extraction and characterization of rubber seed oil. Int. J. Scient. Eng. Sci. 4 (6): 24-27.

Noureddini H, Teoh BC and Clements LD 1992 Viscosities of vegetables oils and fatty acids. J. Am. Oil Chem. Soc. 69(12): 1189-1191.

Olugbemide AD, Labunmi L, Ifijen IH, Ogungbemide DI 2020 Corn stover as substrate for bioenergy generation and precursor for biosilica production via anaerobic digestion. Tanz. J. Sci. 46(3): 807-816.

Onaifo JO, Ikhuoria EU, Omorogbe SO, Agbonlahor OG, Ifijen IH 2016 Coconut pit an alternative source of producing renewable material (bioethanol). J. Appl. Chem. Sci. Int. 6(2): 80-84.

Qian J, Wang F, Liu S and Yun Z 2008 In situ alkaline transesterification of cottonseed oil for production of biodiesel and nontoxic cottonseed meal. Bioresource Technology 99(18): 9009-9012.

Qian J, Yang Q, Sun F, He M, Chen Q, Yun Z and Qin L 2013 Cogeneration of biodiesel and nontoxic rapeseed meal from rapeseed through in-situ alkaline transesterification. Bioresource Technology 128: 8-13.

Selvakumar MJ, Alexis SJ and Raj KS 2015 Emission characteristics of a $\mathrm{Ci}$ engine with the addition of different additives. Int. J.ChemTech Res. 8(4): 2064-2071.

Sinha S, Agarwal KA and Garg S 2008 Biodiesel development from rice bran oil: transesterification process optimization and fuel characterization. Energy Convers. Manag. 49: 1248-1257.

Simasatitkul L, Siricharnsakunchai P, Patcharavorachot Y, Assabumrungrat S and Arpornwichanop A 2011 Reactive distillation for biodiesel production from soybean oil. Korean J. Chem. Eng. 28(3): 649-655.

Thoai DN, Tongurai C, Prasertsit $\mathrm{K}$ and Kumar A 2019 Review on biodiesel production by two-step catalytic conversion. Biocatal. Agric. Biotechnol. 18: 101023.

Zaher F and Gad MS 2016 Assessment of biodiesel derived from waste cooking oil as an alternative fuel for diesel engines. Int. J. ChemTech Res. 9(3): 140-146. 